\title{
EKSISTENSI BAHASA INDONESIA SEBAGAI BAHASA PERSATUAN
}

\author{
Marsudi
}

\begin{abstract}
Abstrak
Bahasa Indonesia lahir dari Bahasa Melayu yang pada zaman dulu menjadi bahasa lingua franca, yakni bagasa perdagangan antarpulau di nusantara. Kemudian dikukuhkan menjadi bahasa persatuan melalui momen Sumpah Pemuda. Bahasa Melayu menjadi dominan di kala itu dikarenakan fleksibelitasnya akan bahasa-bahasa lain. Dengan fakta tersebut, tepatnya 28 Oktober 1928, bahasa Melayu diangkat sebagai bahasa persatuan dan tahun 1945 diresmikan sebagai bahasa negara.

Permasalahan yang muncul dalam eksistensi bahasa Indonesia adalah bagaimanakah cara mempertahankan eksistensi bahasa Indonesia? Tidak hanya masalah eksistensi saja, tetapi sanggupkah bahasa-bahasa daerah di negeri ini memperkaya kosa kata dan istilah bahasa Indonesia? Selain itu, bagaimanakah potensi bahasa Indonesia di era globalisasi?

Eksistensi bahasa Indonesia, selain dipengaruhi kekonsistenan penggunaanya, juga didukung oleh kemampuan bahasa tersebut dalam mengungkapkan fenomena baru yang berkembang. Oleh karena itu, perkembangan bahasa Indonesia sangat tergantung pada tingkat keberhasilan menciptakan kosa kata dan istilah-istilah baru. Bahasa Indonesia sudah mulai mengglobal karena bahasa Indonesia memiliki sifat terbuka dan demokratis. Perkembangan yang terjadi sekarang dan yang datang tidak hanya menyangkut masalah struktur dan bahasa, tetapi lebih jauh mengungkapkan permasalahan manusia baru yang dialami manusia di dalam sebuah proses perubahan dalam berbagai aspek kehidupan.
\end{abstract}

Kata Kunci: eksistensi bahasa, bahasa persatuan, potensi bahasa, globalisasi bahasa.

Bahasa Indonesia lahir pada 28 Oktober 1928 dan dicetuskan sebagai sikap politik para pemuda pada masa itu yang mengakui satu bangsa yaitu bangsa Indonesia, satu tanah air yaitu Indonesia dan satu bahasa yaitu bahasa Indonesia. Berarti, tahun 2008 ini bahasa Indonesia genap berusia 80 tahun dan dalam perjalanan panjangnya bahasa Indonesia telah menempati kedudukan penting sebagai bahasa nasional dan bahasa negara bahkan juga menjadi lambang jati diri bangsa serta alat pemersatu bangsa.

Jsh Jurnal Sosial Humaniora, Vol.1 No.2, November 2008 
Apabila ditinjau dari sejarah, Bahasa Indonesia berasal dari Bahasa Melayu yang digunakan sebagai bahasa perdagangan antarpulau di Nusantara. Dengan munculnya rasa kebangsaan, bahasa Melayu diangkat menjadi Bahasa Persatuan melalui momen Sumpah Pemuda. Bahasa Melayu menjadi sangat dominan di zaman itu dikarenakan fleksibelitasnya akan bahasa-bahasa lain. Karena interaksi bangsa Indonesia saat itu lebih banyak dengan orang-orang berbahasa Arab, Bahasa Arablah yang banyak diserap ke dalam Bahasa Melayu.

Sumpah Pemuda yang diikrarkan 28 Oktober 1928 merupakan wujud kristalisasi semangat nasionalisme sebagai bangsa dijajah oleh bangsa asing. Dengan Sumpah Pemuda tersebut, penggalangan kekuatan guna mempersatukan suku bangsa yang tercerai berai yang terjadi di ribuan pulau negeri ini mulai menampakkkan kesadaran pentingnya hidup bersatu. Bersatu merupakan salah satu modal utama dalam rangka memerdekakan Indonesia. Sumpah Pemuda merupakan bagian dari perjalanan sejarah bahasa Indonesia. Ikrar: satu bahasa, bahasa Indonesia merupakan kekuatan pemersatu suku bangsa Indonesia yang berbeda suku dan bahasa. Kini Indonesia sudah merdeka dan Sumpah Pemuda sudah berusia 80 tahun. Apakah ikrar satu bahasa, yakni bahasa Indonesia masih memiliki kekuatan membangun rasa nasionalisme terhadap bahasa Indonesia?

Pada saat ini permasalahan-permasalahan yang muncul adalah bagaimanakah eksistensi bahasa nasional dalam era globalisasi saat ini? Mampukah bahasa-bahasa daerah di negeri ini mendukung perkembangan bahasa Indonesia di era yang semakin mengglobal? Bagaimanakah gambaran bahasa Indonesia di masa depan?

Kegiatan komunikasi dalam berbagai kesempatan memang banyak masyarakat terbiasa menggunakan bahasa Indonesia. Tidak jarang dijumpai bahwa mereka pun kadang lebih fasih dan memahami bahasa Indonesia daripada bahasa daerahnya. Selain itu, dalam pertemuan-pertemuan resmi pun digunakan bahasa Indonesia. Akan tetapi, fenomena penggunaan bahasa Indonesia sekarang ini menunjukkan bahwa fungsi bahasa Indonesia tidak lagi sama seperti dalam sejarah Sumpah Pemuda tahun 1928. Permasalahan yang terjadi saat ini adalah apakah bangsa Indonesia masih merasa memiliki bahasa Indonesia? Andai bangsa 
ini merasa memiliki bahasa Indonesia kemungkinan masih kurang menunjukkan sikap dan perilaku yang positif.

Bagi sebagian bangsa Indonesia, bahasa Indonesia masih dinilai sebagai bahasa yang inferior. Masyarakat kini gemar menyebut kata asing ketimbang padanannya dalam bahasa Indonesia (http://groups.google.co.id). Bahasa asing dianggap memiliki prestise yang lebih tinggi daripada bahasa Indonesia. Hal ini tampak pada pemakaian kata atau istilah asing yang berarti tidak memiliki kebanggaan terhadap bahasa Indonesia dan tidak mencari kata atau istilah yang berasal dari bahasa Indonesia atau dari bahasa serumpun.

Gejala mengkhawatirkan ini tidak dapat dianggap remeh, sebagai suatu perkembangan yang biasanya muncul dalam masyarakat urban, seperti juga tampak di sejumlah negara lain. Timbulnya gejala bahasa pergaulan, terutama di kalangan muda, dalam masyarakat urban yang rentan terhadap derap globalisasi merupakan fenomena yang dapat kita pahami. Namun, kalau kecerobohan dalam penerapan bahasa Indonesia juga menyelinap di media, biasanya di media elektronik yang dampak jangkauannya lebih mendalam dan meluas dibandingkan dengan media cetak, maka kekhawatiran kita terhadap masa depan bahasa Indonesia bukanlah berlebihan.

Dilihat dari segi kepentingan berbahasa, seseorang/pihak tertentu menggunakan bahasa mengabaikan kebaikan dan kebenaran berbahasa. Misalnya, bahasa Indonesia dipakai oleh sebagian masyarakat untuk menyukseskan kepentingan kelompok tertentu sehingga bisa menimbulkan kerawanan persatuan bangsa. Jika sikap semacam itu berlanjut, bahasa Indonesia tidak lagi berfungsi sebagai bahasa persatuan. Akibatnya, bahasa Indonesia tidak lagi sebagai alat pemersatu, tetapi sebagai alat pemecah belah bangsa. Partai-partai yang bertikai menggunakan bahasa sebagai alat untuk kepentingan partai atau kelompoknya. Para politikus tidak jarang memanfaatkan bahasa untuk mempengaruhi masyarakat agar mendukung partainya, tetapi bahasa Indonesia yang dipakai kurang dan bahkan tidak lagi mencerminkan sebagai bahasa persatuan. Bukanlah fenomena baru jika gara-gara penggunaan bahasa yang kurang santun menjadikan lawan bicara marah/tersinggung padahal tidak ada maksud memancing 
kemarahan. Di gedung DPR, pernah kita saksikan adegan adu fisik yang berawal dari penggunaan bahasa yang tidak santun dalam menyampaikan perbedaan pendapat. Dalam konteks ini pastilah peran bahasa dilupakan untuk mencari titik tengahnya atau menghargai perbedaan pendapat.

Sampai saat ini, patut disyukuri bahwa adanya gejolak dan kerawanan yang mengancam kerukunan dan kesatuan bangsa Indonesia bukanlah bersumber dari bahasa persatuannya, bahasa Indonesia yang dimilikinya, melainkan bersumber dari krisis mutidimensional terutama krisis ekonomi, hukum, dan politik, serta pengaruh globalisasi. Justru, bahasa Indonesia hingga kini menjadi perisai pemersatu yang belum pernah dijadikan sumber permasalahan oleh masyarakat pemakainya yang berasal dari berbagai ragam suku dan daerah. Jika tidak ada Sumpah Pemuda, mungkin negeri ini tidak akan memperoleh kemerdekaan tahun 1945 karena masing-masing suku fanatik menggunakan bahasa daerahnya. Oleh karena itu, adanya bahasa persatuan itulah, rasa nasionalisme terwujud sampai sekarang.

Setiap tahun, Sumpah Pemuda yang diperingati oleh bangsa Indonesia ini juga membuktikan betapa pentingnya bahasa bagi suatu bangsa. Bahasa sebagai alat komunikasi yang paling efektif dibandingkan alat komunikasi yang lain ternyata mutlak diperlukan setiap bangsa. Bangsa yang tidak memiliki bahasa tidak mustahil akan mengalami kemajuan karena bangsa tersebut tidak mungkin menggambarkan dan menunjukkan dirinya secara utuh dalam dunia pergaulan dengan bangsa lain. Akibatnya, bangsa itu akhirnya akan lenyap ditelan masa. Jadi, bahasa menunjukkan identitas bangsa. Bahasa, sebagai bagian kebudayaan dapat menunjukkan tinggi rendahnya kebudayaan bangsa. Bahasa akan menggambarkan sudah sampai seberapa jauh kemajuan yang telah dicapai suatu bangsa. Ikarar "Kami putra dan putri Indonesia, menjunjung tinggi bahasa persatuan, bahasa Indonesia" menjadi dasar yang kokoh bagi kedudukan dan fungsi bahasa Indonesia bagi bangsa Indonesia. Bahkan, pada perjalanan selanjutnya, bahasa Indonesia tidak lagi sebagai bahasa persatuan, tetapi juga berkembang sebagai bahasa negara dan bahasa ilmu pengetahuan dan teknologi. 


\section{Eksistensi Bahasa Persatuan}

Apabila merefleksi kembali ke masa lampau, betapa berat perjuangan bahasa Indonesia, baik sebagai cerminan kehidupan budaya (jati diri bangsa) maupun sebagai sarana komunikasi sosial politik. Betapa tidak, bahasa Indonesia pada waktu itu harus bersaing dengan berbagai bahasa daerah yang tumbuh dan berakar dengan sangat kuat di berbagai suku bangsa. Beruntunglah status bahasa Indonesia karena pendiri republik ini berwawasan luas untuk kepentingan persatuan dan kesatuan bangsa, maka diangkatlah bahasa Melayu yang menjadi cikal bakal bahasa Indonesia.

Eksistensi bahasa persatuan, selain dipengaruhi kekuatutuhan penggunaanya, juga didukung oleh kemampuan bahasa tersebut dalam mengungkapkan fenomena baru yang berkembang. Bahasa secara filosofis adalah pengungkapan manusia atas realitas melalui simbol-simbol. Oleh karena itu, perkembangan Bahasa Indonesia antara lain sangat tergantung pada tingkat keberhasilan menciptakan kosa kata dan istilah-istilah baru.

Kenyataan yang terjadi saat ini adalah bahasa Inggris sebagai alat komunikasi tingkat internasional. Mengingat kedudukan bahasa Inggris tersebut, pengembangan bahasa Indonesia sangat dipengaruhi oleh dinamisasi penyerapan kata-kata dan istilah dalam bahasa Inggris. Penyerapan dalam rangkan pengembangan bahasa ini bukan tanpa risiko. Kalau tanpa kendali, bahasa Indonesia bisa kehilangan jati diri sebagai bahasa nasional. Penyerapan bahasa tidaklah murni pada pengambilan kosa kata saja, tetapi lebih dari itu. Budaya yang melatarbelakangi bahasa tersebut ikut terbawa. Perlu diingat pula, masuknya katakata asing, baik lisan maupun tulis, terus terjadi tanpa teguran sama sekali. Apalagi sanksi atas pelanggaran tersebut, pihak yang berwenang tidak pernah peduli Sehari-hari kita lebih lahap men-caplok kata asing (Inggris) daripada bertaat asas berbahasa Indonesia tanpa berbumbu kata asing. Hal yang perlu diingat bahwa penyerapan bahasa asing ke dalam bahasa Indonesia sekaligus banyak kultur negeri asal bahasa Inggris yang tidak sesuai dengan konteks Indonesia. 
Sudah siapkah bahasa Indonesia digunakan sebagai sarana komunikasi dalam kehidupan global? Masalah kesiapan inilah yang sering dipertanyakan oleh pengguna bahasa Indonesia, terutama yang mebidangi ilmu pengetahuan dan teknologi. Jawaban itu akan terpulang kepada bangsa Indonesia. Jika tidak siap, bahasa Indonesia sebagai identitas bangsa Indonesia akan lenyap. Konsekuensi ancaman tidak hanya sebatas mengancam eksistensi bahasa Indonesia, namun menjadi sangat penting karena berkaitan dengan bahasa sebagai identitas dan kepribadian bangsa (ntoso.wordpress.com/). Langkah utama yang perlu dilakukan ialah pengembangan bahasa Indonesia, terutama kosakata, dan pemantapan sistem bahasa serta peningkatan mutu penggunaannya secara baik dan benar dalam berbagai keperluan.

Satu hal yang perlu disadari bahwa kedinamisan perkembangan ilmu pengetahuan dan teknologi di zaman yang semakin menggelobal ini menuntut bahasa Indonesia memiliki kecendekiaan yang memadai. Bahasa Indonesia saat ini ternyata masih perlu ditingkatkan kecendekiaannya. Penyerapan Bahasa Inggris ke dalam Bahasa Indonesia merupakan salah satu upaya untuk meningkatkan kecendekiaan bahasa Indonesia. Di samping itu, penyerapan bahasa Inggris tersebut merupakan keadaan yang tidak dapat dihindari di era globalisasi. Namun, penyerapan tersebut dilakukan tidak akan meningkatkan dan memantapkan bahasa Indonesia jika tidak diikuti penggunaan bahasa dengan baik dan benar. Pengembangan kosakata tanpa penggunaannya secara tepat tidak akan mendukung upaya pemantapan peran bahasa Indonesia di tengah-tengah persiapan memasuki tatanan kehidupan global (www.feunpak.web.id). Sekali lagi, penyerapan bahasa asing dapat dilakukan dengan syarat tidak meminggirkan atau bahkan menggusur eksistensi bahasa Indonesia, tetapi diharapkan melengkapi kekurangan dalam bahasa Indonesia.

Bahasa Indonesia yang sekaligus sebagai bahasa persatuan dihadapkan pada suatu tantangan yang tidak ringan, antara lain dimanfaatkan dalam bidang ilmu pengetahuan dan teknologi. Apabila dimanfaatkan dalam bidang tersebut, bahasa Indonesia masih kekurangan kosakata termasuk peristilahannya. Berbagai konsep ilmu dan teknologi yang menggunakan bahasa asing belum seluruhnya 
dapat dialihkan dengan cepat ke dalam bahasa Indonesia, walaupun telah tercatat 78.000 lema kata umum dalam Kamus Besar Bahasa Indonesia Edisi Ketiga (2001) dan 264.000 istilah dalam berbagai bidang ilmu.

Selain berbagai faktor internal, faktor eksternal yakni arus globalisasi yang difasilitasi teknologi informasi turut memacu perkembangan bahasa Indonesia, terutama dalam persiapan memasuki tatanan kehidupan dunia yang baru. Sementara itu, perkembangan teknologi informasi yang mampu menerobos batas ruang dan waktu telah memberi peluang keterbukaan yang tidak dapat dihindari. Dengan teknologi itu masyarakat dapat memperoleh berbagai informasi secara langsung melalui radio, televisi, internet, atau media lain.

Tatanan kehidupan dunia yang baru telah membuka lembaran baru dalam kehidupan umat manusia. Kehadiran teknologi informasi (seperti telepon, faksimile, dan internet) dengan kemampuan daya jangkau yang dapat menerobos batas ruang dan waktu telah melahirkan keterbukaan sehingga dunia ini bagaikan sebuah desa global. Teknologi informasi itu menggunakan bahasa sebagai pengantar maka dalam media itu terpajang berbagai macam bahasa dunia. Dalam kondisi seperti itu sebenarnya tidak hanya terjadi persaingan secara terbuka produk dan jasa, tetapi telah terjadi juga persaingan secara terbuka antara bahasa yang satu dan bahasa yang lainnya. Kondisi itu bisa membuat orang berpikir bahwa bahasa menjadi sangat penting bagi kehidupan suatu bangsa. Untuk itu, perlu dilakukan berbagai upaya pemantapan peran bahasa Indonesia, terutama sebagai alat pemersatu bangsa.

Dalam era globalisasi seperti saat ini, bahasa menjadi sangat penting bagi kelangsungan eksistensi persatuan bangsa, baik sebagai lambang jati diri maupun sebagai sarana komunikasi dalam kehidupan bermasyarakat, berbangsa, dan bernegara. Bahkan, bahasa Indonesia berpotensi sebagai bahasa perhubungan luas karena digunakan oleh penduduk besar di kawasan Asia Tenggara dan kini bahasa Indonesia banyak dipelajari di berbagai negara.

Setelah delapan puluh tahun menjadi bahasa persatuan, bahasa Indonesia menunjukkan jati dirinya sebagai alat komunikasi yang mutlak diperlukan bangsa Indonesia. Dalam sejarah perjalannya, Bahasa Indonesia telah mengalami pasang 
surut, tetapi bahasa Indonesia tetap bertahan dan kokoh sebagai bahasa persatuan atau nasional dan bahasa resmi negara. Bahasa Indonesia telah menunjukkan identitas bangsa Indonesia. Bahasa Indonesia sangat berperan dalam mempersatukan belbagai suku bangsa yang beraneka adat dan budayanya. Dalam mengemban misinya, bahasa Indonesia terus berkembang seiring dengan keperluan dan perkembangan bangsa Indonesia, walaupun ada perkembangan yang menggembirakan dan ada perkembangan yang menyedihkan dan membahayakan, Dualisme perkembangan ini memang merupakan dinamika dan konsekuensi bahasa yang hidup. Akan tetapi, karena bahasa Indonesia sudah diposisikan sebagai bahasa yang berkedudukan tinggi oleh bangsa Indonesia, bahasa Indonesia harus dikembangkan ke arah yang lebih baik dan penuh tanggung jawab sehingga ungkapan "bahasa menunjukkan bangsa" benar-benar mengkristal dalam bahasa Indonesia.

\section{Peran Bahasa Daerah terhadap Bahasa Persatuan}

Bahasa daerah merupakan bagian yang integral dari kebudayaan daerah. Sebagai bagian dari kebudayaan daerah, bahasa daerah tentu memberikan andil dalam memperkaya kebudayaan nasional, termasuk di dalamnya memperkaya bahasa Indonesia. Hal ini sejalan dengan pendapat yang mengatakan, Di dalam hubungannya dengan fungsi bahasa Indonesia, bahasa daerah berfungsi sebagai pendukung bahasa nasional (Halim, 1976b:146). Pendapat tersebut dipertegas pendapat Hadiatmaja. Hadiatmaja (2000:37) mengatakan sesungguhnya dalam era yang akan datang sangat diharapkan bahsa daerah dapat saling mengisi dengan bahasa Indonesia (Taha, 2000:37). Masalah kebahasaan merupakan salah satu segi masalah kebudayaan nasional yang perlu ditangani dengan sungguh-sungguh dan berencana agar tujuan akhir pembinaan dan pengembangan bahasa Indonesia dan bahasa daerah, termasuk sastranya, bisa tercapai.

Dalam salah satu ikrar Sumpah Pemuda dinyatakan "menjunjung bahasa persatuan, bahasa Indonesia" merupakan pengakuan terhadap banyak bahasa di Indonesia (746 bahasa). Memang benar, ikrar tersebut menempatkan keutamaan bahasa Indonesia di atas bahasa-bahasa lain dalam konteks kenasionalan. Akan 
tetapi bahasa-bahasa daerah tetap memiliki hak hidup di tengah-tengah masyarakat pendukungnya. Masyarakat penutur bahasa-bahasa daerah itu merupakan rakyat yang mendiami wilayah kepulauan dalam satu kesatuan tanah air Indonesia.

Pengembangan bahasa nasional berhubungan dengan bahasa sumber dari bahasa. Sumber penyerapan bahasa Indonesia yang diutamakan adalah bahasa daerah. Menurut penulis sudah saatnya penyerapan kosa kata bahasa daerah semakin digiatkan. Tidak saja penyerapan ini akan berpengaruh positif pada penguatan persatuan nasional, tetapi juga penting dalam pemeliharaan bahasa daerah yang saat ini mengalami kemunduran luar biasa. Sangat disayangkan potensi kekayaan kosa kata dan makna bahasa daerah yang dekat dalam kesehariaan kita dibiarkan begitu saja.

Untuk mempertahankan jati diri bangsa Indonesia tidak sedikit pengorbanan tenaga dan biaya. Bentuk pengorbanan ini antara lain berupa penelitian-penelitian terhadap bahasa daerah. Hasil penelitian bahasa daerah ini berguna untuk pengembangan bahasa nasional. Di samping itu, pihak atau orang lain akan lebih mudah mempelajari bahasa daerah itu dan penutur asli bahasa daerah pun akan lebih mudah dalam mempelajari bahasa Indonesia. Hasil penelitian bahasa daerah dapat juga dimanfaatkan untuk kegiatan pendidikan dan penyuluhan bagi pemerintah atau pihak-pihak yang membutuhkannya.

Apabila bahasa daerah sebagai sumber penyerapan bahasa Indonesia, kemungkinan yang muncul adalah penggunaan bahasa Indonesia dengan dialek kedaerahan. Tidak dapat dipungkiri, dalam pergaulan kita sering mendengar bahasa Indonesia ala Minang, bahasa Indonesia ala Medan, bahasa Indonesia ala Papua, bahasa Indonesia ala Sunda, bahasa Indonesia ala Jawa, dan sebagainya. Seringkali hal ini membuat risih telinga sehingga terkesan bahasa Indonesia tidak memiliki kriteria standar bahasa Indonesia baku.

Akan tetapi, pengembangan bahasa Indonesia tidaklah selalu mulus dan signifikan pada saat ini. Dalam bidang teknologi misalnya, penyerapan kata dan istilah dari bahasa asing tidak dapat dihindari. Kenyataan ini didasari oleh miskinnya bahasa daerah akan kosa kata bidang teknologi. Akibatnya, 
kelambanan dalam memproduksi kata-kata dan istilah baru membuat bahasa Indonesia menjadi stagnan dan cendrung dianggap sebagai bahasa kuno. Bahasa daerah tidak selalu tersedia kata dan istilah guna pengembangan bahasa nasional. Oleh karena itu, jika hanya bergantung pada bahasa daerah, pengembangan bahasa Indonesia akan mengalami kesulitan.

\section{Potensi Bahasa Indonesia di Masa Depan}

Bahasa Indonesia di masa depan bukan hanya menjadi bahasa negara, melainkan juga menjadi bahasa dari suatu suku bangsa yang mengglobal. Bahasa Indonesia harus mampu mengakomodasi perubahan-perubahan dan penyesuaianpenyesuaian yang mungkin dihadapi. Mekanisme pembinaan dan pengembangan tidaklah ditentukan oleh suatu lembaga, seperti Pusat Bahasa, tetapi akan amat ditentukan oleh mekanisme pasar. Pusat Bahasa tidak perlu terlalu rewel dengan bahasa yang baik dan benar. Politik bahasa yang terlalu bersifat defensif harus ditinggalkan.

Perkembangan yang terjadi sekarang dan yang datang tidak hanya menyangkut masalah struktur dan bahasa, tetapi lebih jauh mengungkapkan permasalahan manusia baru yang dialami manusia di dalam sebuah proses perubahan. Dalam hal ini, permasalahanya adalah bagaimana menjadikan bahasa itu memiliki posisi yang kuat di tengah-tengah masyarakatnya. Atau lebih jauh, bagaimana langkah untuk menjadikan masyarakatnya memiliki posisi kuat di tengah-tengah masyarakat dunia.

Bahasa Indonesia sudah mulai mengglobal. Dewasa ini, bahasa Indonesia merupakan salah satu bahasa asing yang populer dan digemari oleh bangsa lain, dan diajarkan di lebih 140 negara di dunia, seperti Australia, Jepang, RRC, dan Korea Selatan. Di Australia, bahasa Indonesia merupakan satu-satunya bahasa asing yang paling digemari masyarakat, mahasiswa, guru, dosen, dan pegawai negeri. Masyarakat di seluruh negara bagian Australia, kini aktif belajar bahasa Indonesia mulai taman kanak-kanak sampai universitas. Apalagi sekarang, pemerintah Australia telah menjadikan bahasa Indonesia sebagai bahasa kedua di seluruh negara bagian Australia. Prinsip yang perlu diambil adalah bukan sebagai 
objek perubahan dalam era globalisasi, melainkan harus menjadi subjek perubahan sehingga bahasa Indonesia berpotensial menjadi bahasa yang diperhitungkan di dalam dunia global. Bukti-bukti di atas menunjukkan bahwa bahasa Indonesia memiliki potensi menjadi bahasa global. Bahasa Indonesia memiliki potensi dalam mengatasi permasalahan kesiapan memasuki tatanan kehidupan global, seperti perdagangan bebas ataupun teknologi informasi (http://cabiklunik.blogspot.com/).

Bahasa Indonesia bersifat terbuka (transparan). Artinya, bahasa ini dapat beradaptasi dengan bahasa-bahasa lain dan mudah menerima unsur-unsur bahasa asing, seperti unsur fonologi, morfologi, dan unsur semantik. Bahasa Indonesia dapat berkembang dengan pesat terutama di bidang kosakata, seperti ipteks, politik, bisnis, dan lain-lain karena sifatnya yang terbuka tadi. Kata-kata dan istilah dari bahasa Sanskerta, Cina, Jepang, Jawa, Sunda, Arab, Belanda, dan Inggris begitu mudahnya terserap ke dalam bahasa Indonesia.

Bahasa Indonesia memiliki sifat terbuka akan cepat berkembang dan mudah menyesuaikan diri dengan lingkungan dan situasi pasar, sehingga penuturnya tidak terlalu sulit untuk menggunakannya terutama dalam komunikasi bisnis. Sifat terbuka yang dimilikinya merupakan satu potensi bahasa Indonesia pada masa kini dan masa depan, yang kelak diharapkan mampu membawa bahasa Indonesia menuju masyarakat Indonesia baru yang demokratis, egaliter, dan menjunjung tinggi nilai-nilai kebenaran dan keadilan. Dengan sifat terbuka ini pula, diharapkan bahasa Indonesia akan menjadi bahasa yang besar penuturnya menuju peradaban dan kebudayaan Indonesia modern.

Bahasa Indonesia merupakan bahasa yang memiliki sifat demokratis. Ini sesuai dengan karakteristik manusia/masyarakat baru yang menjunjung tinggi nilai-nilai demokrasi. Artinya, bahasa Indonesia tidak mengenal tingkat-tingkat tutur. Bahasa Indonesia memiliki sifat demokratis yang kuat terpadu dengan sistem sosial masyarakat Indonesia. Sifat demokratis bahasa Indonesia terwujud dalam kehidupan berbahasa masyarakat Indonesia, yakni suatu wujud kehidupan yang kurang menampilkan makna orang-seorang sebagai individu. Anjuran pemakaian kata Bung pada pemerintahan lama seperti Bung Karno, Bung Hatta, 
Bung Tomo, Bung Syahrir, dan lain-lain merupakan wujud dari sifat demokratis bahasa Indonesia.

Bahasa yang bersifat demokratis dan merakyat akan semakin banyak penuturnya pada masa kini dan di masa depan. Hal ini telah dimiliki oleh bahasa Indonesia. Oleh karena itu, bahasa Indonesia akan semakin digemari dan banyak penuturnya. Siapa saja yang sudah mengenal dan mempelajari bahasa Indonesia, dia akan semakin menyukainya. Dengan sifat demokratis inilah bahasa Indonesia akan semakin banyak penuturnya dari negara-negara lain.

\section{Simpulan dan Saran}

Sesuai dengan pokok-pokok permasalahan seperti telah dikemukakan di atas, simpulan masalah eksistensi bahasa nasional (Indonesia) dapat dijelaskan sebagai berikut:

a. Eksistensi bahasa persatuan, selain dipengaruhi kekuatutuhan penggunaanya, juga harus didukung oleh kemampuan bahasa tersebut dalam mengungkapkan fenomena baru yang berkembang.

b. Pengembalian bahasa Indonesia menjadi bahasa persatuan adalah dengan cara memberi kesempatan kepada keragaman dan kekayaan bahasa daerah di tanah air untuk menambah perbendaharaan kata bahasa Indonesia.

c. Bahasa Indonesia memiliki potensi besar menjadi "bahasa besar" (bukan hanya bahasa nasional) karena bahasa Indonesia dikembangkan menuju bahasa yang global yang bersifat terbuka dan demokratis.

Setelah membahas eksistensi bahasa nasional, saran yang perlu disampaikan sebagai berikut.

a Sikap positif pemakai bahasa Indonesia harus dimanifestasikan dalam berbahasa,

b. Bahasa Indonesia harus selalu meningkatkan kemampuan mengungkapkan berbagai macam ide, termasuk ilmu pengetahuan dan teknologi. 
c. Bahasa daerah perlu diberi peluang besar guna pengembangan bahasa Indonesia sehingga bahasa Indonesia tetap menunjukkan keindonesiaannya.

d. Dukungan dari berbagai pihak, seperti pemerintah, parlemen, dan pemilikik bahasa Indonesia sangat menentukan eksistensi bahasa Indonesia ditingkat nasional dan bahkan internasional.

\section{Daftar Pustaka}

Hadiatmaja, Sarjana (dalam Murad.A). 1992. "Potensi KosaKata Bahasa Jawa untuk Memperkaya Kosakata Bahasa Indonesia”. Kongres Bahasa Indonesia IV. Jakarta: Pusat Pembinaan dan Pengembangan Bahasa Departemen Pendidikan dan Kebudayaan.

Halim, Amran. 1980. "Fugsi dan Kedudukan Bahasa Indonesia”. Politik Bahasa Nasional 2. Jakarta: Balai Pustaka.

Taha, Zainuddin (penyunting Alwi, Hasan). 2000. "Kedudukan dan Fungsi Bahasa Daerah dalam Era Globalisasi”. Bahasa Indonesia dalam Era Globalisasi: Pemantapan Peran Bahasa sebagai Sarana Pembangunan Bahasa. Jakarta: Pusat Pembinaan dan Pengembangan Bahasa Departemen Pendidikan Nasional.

http://groups.google.co.id/. Diakses 17 Oktober 2008.

http://fiqihsantoso.wordpress.com/2008/01/29/peran-bahasa-indonesia-dalamusaha-persatuan-indonesia/. Diunduh pada tanggal 17 Oktober2008 ntoso.wordpress.com/2008/01/29/peran-bahasa-indonesia-dalam-usaha-persatuanindonesia/). Diunduh pada tanggal 18 Oktober 2008.

http://www.feunpak.web.id/jima/orasi dendysugono.htm. Diunduh pada tanggal 18 Oktober 2008.

http://cabiklunik.blogspot.com/2007/09/bahasa-indonesia-merekat-bangsa.html. Diunduh pada tanggal 18 Oktober 2008. 